\title{
UPAYA MENINGKATAN QAWA'ID BAHASA ARAB MELALUI MODEL PEMBELAJARAN MIND MAP DI PRODI EKONOMI SYARI'AH
}

\author{
Iwan Siswanto
}

(Sekolah Tinggi Ilmu Agama Islam Auliaurrasyidin Tembilahan)

\begin{abstract}
Abstrak
Tujuan penelitian ini adalah untuk meningkatkan qawa'id bahasa arab dengan menggunakan model pembelajaran Mind Mapping. Penelitian ini merupakan penelitian tindakan kelas, yang dilaksanakan dalam dua siklus. Teknik pengumpulan data yang digunakan yaitu: teknik observasi, wawancara, dokumen dan tes. Teknik analisis data yang digunakan adalah model analisis interaktif, yang mempunyai beberapa komponen yaitu: reduksi data, penyajian data, dan penarikan kesimpulan. Berdasarkan hasil penelitian dapat disimpulkan bahwa penggunaan model pembelajaran Mind Mapping dapat meningkatkan qawa'id bahasa arab. Peningkatan qawa'id bahasa arab tersebut dapat dibuktikan dengan meningkatnya nilai qawa'id bahasa arab mahasiswa pada setiap siklus yaitu nilai ratarata qawa'id bahasa arab mahasiswa sebelum tindakan (pra siklus) hanya sebesar 65,2, pada siklus I nilai rata-rata qawa'id bahasa arab mahasiswa menjadi 74,7, dan pada siklus II meningkat menjadi 81,4. Sebelum dilaksanakan tindakan, mahasiswa yang memperoleh nilai diatas kriteria ketuntasan minimal ( $\geq 65)$ hanya sebanyak 9 mahasiswa (33\%), pada siklus I meningkat menjadi 18 mahasiswa (68\%), dan pada siklus II meningkat lagi menjadi 21 mahasiswa (81\%).
\end{abstract}

Kata kunci: Mind Mapping, Bahasa Arab, Qawa'id

\section{A. Pendahuluan}

Pembelajaran bahasa arab dengan berbagai karakteristiknya serta motivasi mempelajarinya di kalangan masyarakat non arab tetap saja memiliki banyak kendala dan problematika yang dihadapi karena bahasa arab tetap bukanlah bahasa yang mudah dikuasai secara total. Problematika 
yang biasanya muncul dalam pembelajaran bahasa arab bagi non arab terbagai ke dalam dua bagian, problematika lingusitik dan non linguistik. Termasuk problem linguistik yaitu tata bunyi, kosakata, tata kalimat dan tulisan. Sementara yang termasuk problem non linguistik yang paling utama adalah problem yang menyangkut perbedaan sosiokultural masyarakat dengan masyarakat non arab. ${ }^{1}$

Kesulitan dalam memahami bahasa arab ada kemungkinan dikarenakan anggapan bahwa khususnya qawa'id bahasa arab sulit, kompleks, dan menakutkan. Qawa'id bahasa arab yang dianggap kompleks dan yang dianggap sulit untuk diterapkan ini menjadikan bahasa arab adalah materi yang dijauhi dan menurunkan motivasi belajar siswa maupun mahasiswa, tidak hanya di lembaga umum tetapi juga di lembaga islam sendiri. Pembelajaran qawa'id adalah proses interaksi peserta didik dengan lingkungannya dalam hal ini materi qawa'id sehingga terjadi perubahan perilaku peserta didik di mana mereka dapat memahami, mengerti dan menguasai qawa'id dan diharapkan mereka mampu berkomunikasi dengan menggunakan bahasa arab dengan baik dan benar.

Anggapan bahwa qawa'id bahasa arab itu kompleks dan sulit dikarenakan beberapa sumber belajar, bahan ajar, buku-buku qawa'id terkesan tradisional, tebal dan sedikit membosankan dengan tulisan yang tidak terlalu besar, tidak adanya ilustrasi gambar ataupun warna, dan kurang menarik serta menurunkan minat untuk mempelajarinya. Pada umumnya bahan ajar yang digunakan dalam hal ini terutama buku ajar di banyak lembaga pendidikan Islam di Indonesia, seperti madrasah, pesantren, perguruan tinggi Islam, masih merupakan "karya lama", yang biasanya disebut dengan "kitab kuning" sebuah sebutan yang menunjukkan jenis buku yang umumnya berwarna kuning. Peran bahan ajar sangat penting

${ }^{1}$ Acep Hermawan, Metodologi Pembelajaran Bahasa Arab, (Bandung: Remaja Rosdakarya, 2011), 100 
dalam proses pembelajaran. Jika sumber belajar dan bahan ajar kurang menarik atau terkesan monoton, maka akan menurunkan minat dan motivasi belajar siswa ataupun mahasiswa. Dengan ini bisa terjadi pembelajaran yang berhasil.

Sampai saat ini bahan-bahan ajar bahasa arab yang berkembang dan banyak digunakan di Indonesia pada umumnya adalah bahan ajar yang biasa digunakan di madrasah-madrasah di Timur Tengah, ${ }^{2}$ dan kalaupun bahan ajar tersebut adalah hasil pengembangan, maka jumlahnya tidaklah begitu banyak.. Sementara tuntutan masyarakat akademik mengenai perlunya inovasi dan pengembangan bahan ajar bahasa arab, dewasa ini terus bergulir, seiring dengan dinamika perkembangan ilmu pengetahuan dan teknologi. Selain itu, tuntutan adanya bahan ajar Arab yang menggunakan bahasa indonesia sebagai bahasa pengantarnya berkembang di sebagian peserta didik, terutama mereka yang berlatar belakang pendidikan umum.

Berdasarkan hasil pengamatan dan wawancara pada hari Kamis, 25 Agustus 2016 menunjukkan bahwa pembelajaran Bahasa Arab di Prodi Ekonomi Syari'ah kelas A Sekolah Tinggi Agama Islam Auliyaurrasyidin Tembilahan, khususnya terhadap qawa'id bahasa arab masih rendah. Hasil evaluasi dari 32 Mahasiswa, 21 mahasiswa atau 67\% siswa masih mendapat nilai di bawah Kriteria Ketuntasan Minimal (KKM) bahasa arab yang ditetapkan yaitu 65 dan 11 siswa atau 33\% siswa sudah mencapai KKM dengan rata-rata kelas 65,2.

Hasil observasi dan wawancara yang telah dilakukan peneliti, menunjukkan bahwa masih rendahnya hasil pencapaian tersebut disebabkan oleh beberapa faktor. Faktor tersebut dapat digolongkan menjadi faktor

2 Misalnya bahan ajar yang digunakan untuk mata pelajaran balaghah, seperti kitab Jawâhir al-Balaghah karya al Jurjani, Jauhar Maknûn karya al-Akhdari, dan alBalaghah al- Wâdhihah karya Ali al-Jarim dan Mustafa Amin. Dewasa ini kitab-kitab tersebut merupakan rujukan bagi para guru dan dosen yang mengajarkan Balaghah sampai sekarang. 
intern dan faktor ekstern. Faktor intern adalah faktor yang berasal dari dalam diri mahasiswa meliputi: kemampuan berpikir, konsentrasi, dan keantusiasan mengikuti pembelajaran. Hal itu dapat terlihat saat berlangsungnya proses pembelajaran di ruang perkuliyahan. Menyimpangnya aktivitas mahasiswa tersebut disebabkan karena mahasiswa merasa bosan dalam pembelajaran. Sedangkan faktor ekstern yang berasal dari luar diri mahasiswa, yaitu: saat proses pembelajaran berlangsung, metode ceramah masih mendominasi.

Dosen sebagai orang yang berpengaruh besar di ruang kuliyah harus mampu mengembangkan kemampuannya untuk menjadi fasilitator yang baik, mampu menciptakan pembelajaran yang aktif, inovatif, kreatif, efektif dan menyenangkan (PAIKEM). Penerapan model pembelajaran yang sesuai dengan karakter mahasiswa dapat lebih meningkatkan minat mahasiswa dalam belajar dan menciptakan suasana belajar menjadi lebih aktif.

Salah satu model pembelajaran yang sesuai dengan karakter mahasiswa adalah model pembelajaran Mind Mapping. Karena dengan menggunakan Mind Mapping ini mahasiswa dapat berimajinasi untuk membuat atau merangkai kata-kata dengan sederhana sesuai bahasa mereka sendiri. Mind Mapping adalah cara mencatat yang kreatif, efektif, dan secara hafiah yang akan "memetakan" pikiran. ${ }^{3}$

Pemetaan pikiran atau mind mapping yang dicetuskan oleh Buzan merupakan teknik visualisasi verbal ke dalam gambar. Peta pikiran sangat bermanfaat untuk memahami materi, terutama materi yang diberikan secara verbal. Peta pikiran bertujuan membuat materi pelajaran terpola secara visual dan grafis yang akhirnya dapat membantu merekam, memperkuat, dan mengingat kemabli informasi yang telah dipelajari. Lebih dari itu, peta pikiran mendorong pemecahan masalah secara kreatif, dan mereka

\footnotetext{
${ }^{3}$ Tony Buzan, Buku Pintar Mind Map, (Jakarta: Gramedia Pustaka, 2012), 4
} 
menyimpan informasi dalam format yang pikiran anda menemukan mudah diingat dan cepat untuk meninjau. ${ }^{4}$ Mind mapping is a creativity and productivity-enhancing technique that can improve the learning and efficiency of individuals and organizations. It is a revolutionary system for capturing ideas and insights horizontally on paper. ${ }^{5}$ Pendapat tersebut dapat diartikan bahwa peta pikiran adalah tekhnik kreativitas dan perbaikan produktivitas yang bisa meningkatkan pembelajaran dan efisiensi dari individu dan kelompok. Ini adalah sistem revolusioner untuk menangkap ide dan wawasan pada kertas horisontal.

Buzan mengungkapkan bahwa, Mind Mapping adalah alat berfikir kreatif yang mencerminkan cara kerja alami otak. Mind Mapping memungkinkan otak menggunakan semua gambar dan asosiasinya dalam pola radial dan jaringan sebagaimana otak dirancang, seperti yang secara internal selalu digunakan otak, dan terhadap mana anda perlu membiarkanya membiasakan diri kembali. ${ }^{6}$ Mind maps help students learn information by forcing them to organize it and add images and color to it. These maps have been shown to lower extrinsic cognitive load because students are creating a two-dimensional space to tie in ideas and concepts that relate together. ${ }^{7}$ Pendapat tersebut dapat diartikan bahwa Mind Map membantu siswa belajar informasi dengan gaya mereka sendiri untuk mengaturnya dan meningkatkan imajinasi serta memberikan warna pada informasi. Peta pikiran tersebut menunjukkan bahwa muatan kesadaran ekstrinsik lebih rendah karena para siswa sedang menciptakan sebuah tempat dua dimensi

4 Tony Buzan, Mind Map Untuk Meningkatkan Kreativitas, (Jakarta: Gramedia, 2009), 15

5 A. Mento, Mind Mapping in Executive Education: Applications and Outcomes. Diperoleh 2016 dari http://www.georgiasouthern.edu/ijsotl.

${ }^{6}$ Tony Buzan, Buku Mind Pintar Mind Map Untuk Anak, (Jakarta: Gramedia Pustaka, 2007), 107

7 B. Jones, The Effects of Mind Mapping Activities on Students' Motivation. Diperoleh Januari 2016 dari http://www.georgiasouthern.edu/ijsotl. 
kemudian menyatukan dalam ide dan konsep-konsep yang dihubungkan bersama.

Model pembelajaran Mind Mapping dimulai dengan menyiapkan kertas kosong tak bergaris, pena dan pensil warna, otak, dan imajinasi. Cara kerja atau langkah membuat Mind Map: (1) Mulai dari bagian tengah, karena memulai dari tengah memberi kebebasan kepada otak untuk menyebar ke segala arah dan untuk mengungkapkan dirinya dengan lebih bebas dan alami, dalam hal ini masih bisa fleksibel bisa memulai dari mana saja yang dianggap lebih mudah. (2) Menggunakan gambar atau foto untuk ide sentral, karena sebuah gambar bermakna seribu kata dan membantu menggunakan imajinasi. Sebuah gambar sentral akan lebih menarik, membuat lebih terfokus, membantu berkonsentrasi, dan mengaktifkan otak. (3) Menggunakan warna, karena bagi otak, warna sama menariknya dengan gambar. Warna membuat Mind Map lebih hidup, menambah energi kepada pemikiran kreatif dan menyenangkan. (4) Menghubungkan cabang-cabang utama ke gambar pusat dan menghubungkan cabang-cabang tingkat dua dan tiga ke tingkat satu dan dua, dan seterusnya, karena otak bekerja menurut asosiasi. Otak senang mengaitkan dua (atau tiga, atau empat) hal sekaligus. Bila menghubungkan cabang-cabang akan lebih mudah mengerti dan mengingat. (5) Membuat garis hubung yang melengkung, karena garis lurus akan membosankan otak. Cabang-cabang yang organis, seperti cabangcabang pohon, jauh lebih menarik bagi mata. (6) Menggunakan satu kata kunci untuk setiap garis,karena kata kunci tunggal memberi lebih banyak daya dan fleksibilitas kepada Mind Map.

Upaya untuk meningkatkan pembelajaran qawaid bahasa arab yang menyenangkan perlu dikembangkan dan diteliti lebih lanjut, salah satunya dengan pembelajaran qawaid bahasa arab dengan menggunakan mind mapping. Maka perlu adanya penelitian upaya untuk meningkatkan pembelajaran qawaid bahasa arab agar lebih mudah difahami, dicerna dan 
meningkatkan motivasi belajar mahasiswa Prodi Ekonomi Syari'ah Sekolah Tinggi Agama Islam Auliyaurrasyidin Tembilahan.

\section{B. Metode}

Penelitian ini dilaksanakan di Sekolah Tinggi Agama Islam Auliyaurrasyidin Tembilahan Prodi Ekonomi Syari'ah semester ganjil 2016/2017. Subjek penelitian ini adalah kelas A dengan jumlah 32 mahasiswa yang terdiri dari 14 laki-laki dan 18 perempuan. Waktu penelitian adalah selama lima bulan, pada bulan September 2016 sampai dengan bulan Januari 2017.

Sumber data dalam penelitian ini adalah dari informan, tempat terjadinya aktivitas pembelajaran dan dokumen. Teknik yang digunakan dalam pengumpulan data yaitu observasi, wawancara, dokumen dan tes. Penggunaan metode ini disesuaikan dengan data yang dibutuhkan. Adapun dalam penelitian ini keempat teknik tersebut digunakan secara kontinyu dan saling melengkapi. Obeservasi digunakan untuk mengamati bahan pembelajaran qawa'id bahasa arab secara mendalam yang sesuai dengan kondisi mahasiswa, serta untuk mengamati proses pembelajaran dengan menggunakan media pembelajaran mind map. Observasi mendalam dilakukan dengan pengamatan dan catatan lapangan yang intensif selama proses pembelajaran qawa'id mengguanakan media mind map tersebut. Wawancara untuk menggali data tentang pembelajaran bahasa arab, juga sebagai mencari tanggapan tentang tentang pembelajaran qawaid dengan menggunakan mind map.

Sedangkan tes digunakan untuk memperoleh hasil nilai dalam pembelajaran qawaid dalam hal ini akan diujicobakan pada mahasiswa Program Studi Ekonomi Sya'riah kelas A Sekolah Tinggi Agama Islam (STAI) Auliyaurrasyidin Tembilahan. 
Sedangkan alat yang digunakan yaitu: lembar observasi, pedoman wawancara dan butir-butir soal. Dengan validitas data yang digunakan yaitu triangulasi sumber dan triangulasi metode. Sedangkan data yang diperoleh dalam penelitian ini dianalisis melalui model analisis interaktif. Penelitian tindakan kelas ini menggunakan prosedur penelitian model Suharsimi Arikunto yang meliputi empat tahap, yaitu: perencanaan, pelaksanaan tindakan, pengamatan, dan refleksi. ${ }^{8}$

\section{Hasil}

Sebelum melaksanakan tindakan, peneliti melakukan kegiatan observasi dan memberikan tes awal. Hasil tes awal tersebut menunjukkan bahwa sebagian besar nilai mahasiswa masih di bawah KKM. Hasil selengkapnya dapat dilihat pada Tabel 1. sebagai berikut:

Tabel 1. Distribusi Frekuensi Data Nilai Tes Awal

\begin{tabular}{|c|c|c|c|}
\hline Interval & Nilai Tengah & Frekuensi & Presentase (\%) \\
\hline $39-47$ & 43 & 3 & 8 \\
\hline $48-56$ & 52 & 6 & 14 \\
\hline $57-65$ & 61 & 13 & 10 \\
\hline $66-74$ & 70 & 2 & 20 \\
\hline $75-83$ & 79 & 3 & 38 \\
\hline $84-92$ & 88 & 32 & 100 \\
\hline
\end{tabular}

Berdasarkan data di atas, sebagian mahasiswa belum mencapai kriteria ketuntasan minimal yang telah ditetapkan yaitu 66. Dari 32

${ }^{8}$ Suharsimi Arikunto, Penelitian Tindakan Kelas, (Jakarta: Bumi Aksara, 2011), 74 
mahasiswa, 22 di antaranya atau 67\% mahasiswa masih di bawah KKM dan hanya 10 mahasiswa atau 33\% mahasiswa yang mencapai KKM. Dengan nilai terendah 39, nilai tertinggi 90 dan nilai rata-rata kelas 65,2.

Nilai qawa'id bahasa arab setelah menggunakan model pembelajaran Mind Mapping pada siklus I menunjukkan adanya peningkatan. Hasil tes qawa'id bahasa arab pada siklus I dapat dilihat pada Tabel 2 sebagai berikut:

Tabel 2. Distribusi Frekuensi Data Nilai Siklus I

\begin{tabular}{|c|c|c|c|}
\hline Interval & Nilai Tengah & Frekuensi & Presentase (\%) \\
\hline $40-48$ & 44 & 2 & 8 \\
\hline $49-57$ & 53 & 4 & 10 \\
\hline $58-66$ & 62 & 5 & 8 \\
\hline $67-75$ & 71 & 3 & 20 \\
\hline $76-84$ & 80 & 5 & 30 \\
\hline $85-93$ & 89 & 10 & 10 \\
\hline $94-102$ & 98 & 3 & 100 \\
\hline \multicolumn{2}{|c|}{ Jumlah } & 32 & \\
\hline
\end{tabular}

Pada siklus I ada 21 mahasiswa yang mencapai batas nilai KKM atau 67\% dan 11 mahasiswa memperoleh nilai di bawah KKM atau 33\%. Nilai terendah 40, nilai tertinggi 95 dan rata-rata nilai 74,7. Dengan demikian target pada indikator kinerja belum tercapai, sehingga dilanjutkan siklus II.

Pada siklus II nilai qawa'id bahasa arab menunjukkan adanya peningkatan. Hasil selengkapnya dapat dilihat pada Tabel 3 sebagai berikut:

Tabel 3. Distribusi Frekuensi Data Nilai Siklus II

\begin{tabular}{|c|c|c|c|}
\hline Interval & Nilai Tengah & Frekuensi & Presentase (\%) \\
\hline $50-58$ & 54 & 3 & 8 \\
\hline $59-67$ & 63 & 5 & 14 \\
\hline
\end{tabular}




\begin{tabular}{|c|c|c|c|}
\hline $68-76$ & 72 & 4 & 10 \\
\hline $77-85$ & 81 & 6 & 20 \\
\hline $86-94$ & 90 & 10 & 38 \\
\hline $95-103$ & 99 & 4 & 10 \\
\hline \multicolumn{2}{|c|}{ Jumlah } & 32 & 100 \\
\hline
\end{tabular}

Setelah dilaksanakan tindakan siklus II data yang diperoleh menunjukkan bahwa ada 24 mahasiswa atau $81 \%$ yang mendapatkan nilai di atas KKM, dan 8 mahasiswa atau 19\% yang mendapatkan nilai dibawah KKM. Nilai terendah 50, nilai tertinggi 100 dengan nilai rata-rata 81,4. Hasil qawa'id bahasa arab siklus II meningkat dan telah mencapai indikator kinerja yaitu $80 \%$, oleh karena itu peneliti mengakhiri tindakan dalam pembelajaran qawa'id bahasa arab.

\section{Pembahasan}

Berdasarkan hasil pengamatan dan analisis data yang telah diperoleh, dapat dinyatakan bahwa pembelajaran bahasa arab dengan menggunakan model pembelajaran Mind Mapping dapat meningkatkan qawa'id bahasa arab pada mahasiswa Prodi Ekonomi Syari'ah. Pada tes awal qawa'id bahasa arab pada mahasiswa, diperoleh nilai rata-rata kelas 65,2 di mana hasil tersebut masih rendah dari kriteria ketuntasan minimal yang telah ditetapkan yaitu $\geq 65$. Sedangkan besarnya persentase siswa yang belajar tuntas hanya sebesar 33\%, sedangkan $81 \%$ lainnya masih belum memenuhi KKM. Nilai terendah pada tes awal adalah sebesar 39, sedangkan nilai tertinggi yang diperoleh siswa adalah 90. Berdasarkan hasil analisis tes awal tersebut, maka dilakukan tindakan yang berupa penelitian tindakan kelas untuk meningkatkan qawa'id bahasa arab pada mahasiswa dengan menggunakan model pembelajaran Mind Mapping. 
Pembelajaran siklus I menggunakan model pembelajaran Mind Mapping menunjukkan adanya peningkatan qawai'id bahasa arab pada mahasiswa. Hasil analisis data nilai qawa'id bahasa arab pada tes siklus I menunjukkan bahwa persentase hasil tes mahasiswa yang belajar tuntas naik sebesar 35\% dibandingkan sebelum tindakan. Mahasiswa yang belajar tuntas pada siklus I sebanyak 18 mahasiswa atau sebesar $67 \%$.

Peningkatan tersebut belum memenuhi target atau indikator keberhasilan yang telah ditetapkan. Selain itu juga masih terdapat beberapa kekurangan dalam pelaksaan pembelajaran. Aktivitas mahasiswa yang perlu diperbaiki yaitu: (a) interaksi/keterlibatan mahasiswa dalam pembelajaran menggunakan model mind mapping; (b) ketenangan atau ketertiban dalam mengikuti proses pembelajaran. Untuk memperbaiki aktivitas-aktivitas mahasiswa tersebut, maka perlu perbaikan kinerja dosen (peneliti) yaitu dalam: (a) pengelolaan kelas kuliyah saat praktikum di luar kelas kuliyah; (b) pemberian umpan balik (motivasi serta respon positif) terhadap partisipasi mahasiswa.

Setelah dilakukan analisa mengenai kekurangan pada pelaksanaan siklus I, maka disusun rencana pembelajaran siklus II agar kekurangan yang terjadi pada siklus I lebih diminimalisir. Pelaksanakan tindakan pada siklus II berjalan lancar dan sesuai perencanaan.

Aktivitas mahasiswa dalam pembelajaran menggunakan model pembelajaran Mind Mapping pada siklus II ini sudah lebih baik dan meningkat. Peningkatan yang sangat terlihat, yaitu: (a) pembuatan Mind Mapping sudah lebih baik dan menarik; (b) ketenangan atau ketertiban dalam mengikuti proses pembelajaran; (c) keberanian mahasiswa untuk memberikan pendapat dan mempresentasikan hasil kerjanya, serta (d) antusiasme mahasiswa dalam mempresentasikan hasil kerjanya. 
Data perbandingan nilai penerapan konsep gaya pada mahasiswa sebelum tindakan, setelah siklus I dan siklus II dapat dilihat pada Tabel 4 sebagai berikut:

Tabel 4. Pebandingan Hasil Tes Qawa'id Bahasa Arab Sebelum Tindakan, Setelah Tindakan Siklus I dan Siklus II

\begin{tabular}{|c|c|c|c|}
\hline \multirow{2}{*}{ Kriteria } & \multicolumn{3}{|c|}{ Kondisi } \\
\cline { 2 - 4 } & Awal & $\begin{array}{c}\text { Siklus } \\
\text { I }\end{array}$ & $\begin{array}{c}\text { Siklus } \\
\text { II }\end{array}$ \\
\hline Nilai Terendah & 39 & 40 & 50 \\
\hline Nilai Tertinggi & 90 & 95 & 100 \\
\hline Nilai Rata-Rata & 65,2 & 74,7 & 81,4 \\
\hline Jumlah Mahasiswa Belajar Tuntas & 10 & 21 & 24 \\
\hline Persentase Ketuntasan & $33 \%$ & $67 \%$ & $81 \%$ \\
\hline
\end{tabular}

Hasil analisis pada siklus II menunjukkan adanya peningkatan qawa'id bahasa arab pada mahasiswa, dengan 24 mahasiswa atau $81 \%$ mencapai KKM, dengan nilai ratarata kelas 81,4.

\section{E. Kesimpulan}

Penelitian tindakan kelas dalam dua siklus dapat diperoleh hasil sebagai berikut: pada kondisi awal sebelum dilaksanakan tindakan (prasiklus) nilai rata-rata mahasiswa 65,2 dengan persentase ketuntasan klasikal 33\%, siklus I dengan nilai ratarata kelas 74,7 dengan persentase ketuntasan klasikal sebesar 67\%, dan siklus II nilai rata-rata kelas 81,4 dengan persentase ketuntasan mencapai $81 \%$. Berdasarkan data yang diperoleh tersebut dapat disimpulkan bahwa penggunaan model Pembelajaran Mind Mapping dapat meningkatkan qawa'id bahasa arab pada mahasiswa Prodi Ekonomi Syari'ah Sekolah Tinggi Agama Islam Auliyaurrasyidin Tembilahan tahun ajaran 2016/2017. 
Referensi

Al-Fakih, Abdullah bin Ahmad. Al-Fawakih Al-Janiyyah Mutammimah, Ala Syarhi Al-Jurumiyah. Surabaya: Bungkul Indah. 1979.

Arikunto, Suharsimi. Penelitian Tindakan Kelas. Jakarta: Bumi Aksara. 2011.

Busri, Hasan. Pelaksanaan Kurikulum Tingkat Satuan Pendidikan (KTSP) Bahasa Arab di Madrasah Aliyah (Studi Kasus Madrasah Aliyah Kabupaten Grobogan). Tesis. IAIN Walisongo Semarang. 2008.

Buzan, Tony. Mind Map Untuk Meningkatkan Kreativitas. Jakarta : PT Gramedia. 2009.

Effendy, Fuad. Metodologi Pengajaran Bahasa Arab. Malang: Misykat. 2009.

Hermawan, Acep. Metodologi Pembelajaran Bahasa Arab. Bandung: Remaja Rosdakarya. 2011.

Makruf, Imam. Strategi Pembelajaran Bahasa Arab Aktif. Semarang: Needs Press 2009.

Munawwir, Ahmad Warson. Kamus Al-Munawir Arab-Indonesia. Cet. Kedua. Surabaya: Pustaka Progressif. 2002.

Sanjaya, Wina. Pembelajaran dalam Implementasi Kurikulum Berbasis Kompetensi. Jakarta: Kencana Prenada Media Group. 2006. 